Article

\title{
Life Cycle Assessment of Cross-Laminated Timber Transportation from Three Origin Points
}

\author{
Mahboobeh Hemmati ${ }^{1, *}$, Tahar Messadi ${ }^{2, *}$ and Hongmei Gu ${ }^{3}$ (D) \\ 1 Environmental Dynamics Ph.D. Program, Graduate School and International Education, \\ University of Arkansas, Fayetteville, AR 72701, USA \\ 2 Fay Jones School of Architecture and Design, University of Arkansas, Fayetteville, AR 72701, USA \\ 3 USDA Forest Service, Forest Products Laboratory, Madison, WI 53726, USA; hongmei.gu@usda.gov \\ * Correspondence: mhemmati@uark.edu (M.H.); tmessadi@uark.edu (T.M.)
}

check for updates

Citation: Hemmati, M.; Messadi, T.; $\mathrm{Gu}, \mathrm{H}$. Life Cycle Assessment of

Cross-Laminated Timber

Transportation from Three Origin

Points. Sustainability 2022, 14, 336.

https://doi.org/10.3390/su14010336

Academic Editor: Luca D'Acierno

Received: 13 November 2021

Accepted: 25 December 2021

Published: 29 December 2021

Publisher's Note: MDPI stays neutral with regard to jurisdictional claims in published maps and institutional affiliations.

Copyright: () 2021 by the authors Licensee MDPI, Basel, Switzerland. This article is an open access article distributed under the terms and conditions of the Creative Commons Attribution (CC BY) license (https:// creativecommons.org/licenses/by/ $4.0 /)$.

\begin{abstract}
Cross-laminated timber (CLT) used in the U.S. is mainly imported from abroad. In the existing literature, however, there are data on domestic transportation, but little understanding exists about the environmental impacts from the CLT import. Most studies use travel distances to the site based on domestic supply origins. The new Adohi Hall building at the University of Arkansas campus, Fayetteville, AR, presents the opportunity to address the multimodal transportation with overseas origin, and to use real data gathered from transporters and manufacturers. The comparison targets the environmental impacts of CLT from an overseas transportation route (Austria-Fayetteville, AR) to two other local transportation lines. The global warming potential (GWP) impact, from various transportation systems, constitutes the assessment metric. The findings demonstrate that transportation by water results in the least greenhouse gas (GHG) emission compared with freight transportation by rail and road. Transportation by rail is the second most efficient, and by road the least environmentally efficient. On the other hand, the comparison of the life cycle assessment (LCA) tools, SimaPro (Ecoinvent database) and Tally (GaBi database), used in this research, indicate a remarkable difference in GWP characterization impact factors per tonne. $\mathrm{km}(\mathrm{tkm})$, primarily due to the different database used by each software.
\end{abstract}

Keywords: life cycle assessment; mass timber; cross-laminated timber; transport; global warming potential; SimaPro; Tally

\section{Introduction}

The building and construction sectors are profoundly affecting global climate. The United States Environmental Protection Agency's (EPA) statistical summary published in 2004 suggests that "the building industry is a major contributor to this impact" [1] (p. 11). Architects, engineers, builders, and involved stakeholders in the building industry are, therefore, looking for approaches to reduce both excessive fossil fuel use and greenhouse gas (GHG) emission generated in the building sector. The GHG emission reduction and sustainability development goals could not be achieved without considering the crucial role of the building industry, which is responsible for one-third of global carbon emissions [2,3].

Traditionally, commercial and mid-to-high residential buildings are constructed with concrete and steel. With new engineered mass timber products emerging in the building sector, such as cross-laminated timber (CLT), mass timber buildings are on the horizon. Previous literature confirmed that replacing concrete and steel with mass timber products can play a significant role in reducing the whole building GHG emissions [4-12]. Sustainability benefits of this new building material are gaining momentum as being environmentally efficient relative to conventional building materials. Despite these benefits, however, CLT is not as available as concrete or steel in the United States [6]. CLT used in the United States is mainly imported from abroad, although more and more production plants for this material 
are emerging in the U.S. Transportation of materials would, therefore, influence the overall life cycle impact of a building. Figure 1 shows the global $\mathrm{CO}_{2}$ emission inherent in each sector, with transportation as the second largest source, producing $23 \%$.

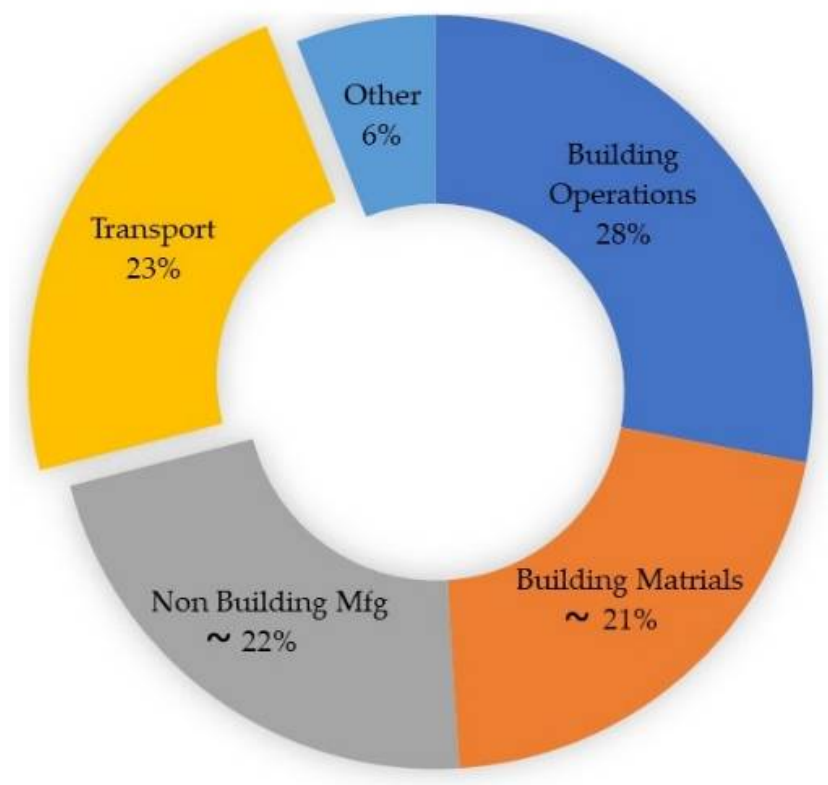

Figure 1. Global $\mathrm{CO}_{2}$ emission by sector (Adapted from "https: / carbonleadershipforum.org/thecarbon-challenge" [13] (accessed on 5 February 2021)).

In the existing literature, however, there is data on domestic transportation of other materials, but the environmental impacts resulting from the CLT import are not very well comprehended. While there are many studies that have focused on LCA use and operation stage, those that have investigated the environmental impacts associated with transportation are far and few in between, and as a result the transportation effects of mass timber remain to be determined [14]. Moreover, in most studies the travel distance to the project site is assumed to be based upon either the domestic supply origins or the typical radius with length less or equal to 500 miles travel, a guideline promoted in the new construction manual of Leadership Energy and Environmental Design (LEED).

In a study by Bribián et al. [15] to compare the environmental impacts associated with common construction materials through the life of a building, the work was based on an assumed average of $100 \mathrm{~km}$ travel distance, which is quite different from those under consideration in this study. In a recent article, Chen et al. [14] examined the impact of two parameters: Travel distance from mills to the site and wood species. They concluded that the decrease of transportation distance reduces the GWP by up to $14 \%$. Again, this finding applies to local transportation. Liu et al. [11] research was focused on the LCA of a building in China but with an assumed road transportation distance of only $300 \mathrm{~km}$ distance from the construction site. The issue of variability associated with distance and modes of transportation is not, however, considered in such a study [14]. Another relevant research by Passarelli et al. [16] compared three different multimodal transport combinations in Japan. The results indicate that the GWP of CLT transportation from another continent is higher than the production stage. This study and related findings serve as a precedent for our research in the U.S. The study by Liang et al. [17] even considered four scenarios of CLT transportation from abroad (Austria, Canada) and from local origin (northwest region of the U.S.) to the site. The results show a dramatic variation ranging between 3.4 to $47 \mathrm{~kg} \mathrm{CO}_{2}$-eq per $\mathrm{m}^{2}$ mass timber floor area, which calls for more studies to confirm or dispute these outcomes. Furthermore, mostly default data were applied to this research. Emami et al.'s [18] investigation shows higher GWP by $5.6 \%$ between imported material from Germany in comparison to local Iceland products. The focus was, however, 
on cement as opposed to mass timber. As evidenced by past research mentioned above, transportation's environmental impact needs further studies, particularly the shipment of materials from abroad.

The newly built CLT Adohi Hall on the campus of the University of Arkansas in Fayetteville, AR, presents the ideal opportunity to also address the issue of multimodal transportation, including overseas origin, with real data gathered directly from the manufacturer and the transporters. As the main purpose of this research, the environmental impacts of the CLT transported from Austria to the project site are compared to those of CLT hauled from two U.S. plants to the same destination.

\section{Research Approach}

\subsection{Quantitative Method}

A quantitative method is deployed to compare 3 paths of CLT transportation with different origins using the life cycle assessment (LCA) tool designed to comprehensively determine the environmental load of a product throughout its whole life cycle. In this approach, the analysis is conducted using real numerical data which are directly collected from the manufacturer and the various transporters through the three modes: Water, road, and rail.

Among the many tools for evaluating the environmental impacts of products and buildings, LCA is the most comprehensive and accounts for all effects through the whole life cycle of a product, from raw materials extraction to the end of life (reusing, recycling, or disposing) [19]. LCA can consider all dimensions of a system, regardless of whether they are input resources, such as energy, material, and services, or outputs, such as emissions [18]. Using LCA, hot spots for the most environmental impacts in a product system can be identified. Thus, LCA provides the opportunity for effective action in reducing environmental impacts by focusing on these hot spots [20]. As defined by the International Organization for Standardization (ISO), the purpose of this tool is to compute and analyze "the inputs, outputs and potential environmental impacts of a product system throughout its life cycle" [21] (p. 7), ISO 14040:2006 describes the principles and framework for LCA, and ISO 14044:2006 specifies requirements and provides guidelines. Accordingly, the run of an LCA for a given project calls for four steps: Goal and scope definition, inventory analysis, impact assessment, and interpretation [22]. Browne et al. [23], Farkavcova et al. [19], Fries et al. [24], and Meisterling et al. [25] all consider LCA a reliable tool for calculating the environmental impacts of transportation.

The LCA analysis tools are highly sensitive to the reliability of the databases. The uniformity of the databases is, therefore, a major issue in using this investigative tool [26-28] and, up to date, not enough studies compared LCA tools and databases to examine the level of consistency given by different tools and databases. So, there is a need for more comparisons between various simulation tools. Thus, the use of two LCA simulation tools and databases to determine Adohi Hall environmental impact is part of this research; the objectives are detailed below.

\subsection{Goals and Objectives}

The first objective of this study is the comparison of three reference origin points of CLT supply for the Adohi Hall building to determine environmental impacts of transportation. The main parameter investigated in this research is the impact of the global warming potential (GWP) due to the transportation process of CLT from the manufacturing plant to Adohi Hall construction site. Furthermore, only GWP is addressed in this study because the building industry recognizes GWP, expressed in $\mathrm{kgCO}_{2} \mathrm{eq}$, as the major factor impacting global warming.

The second objective is to compare the output results when using different LCA tools, SimaPro with Ecoinvent database and Tally with GaBi database, gauge the uniformity of results, and assess their accuracy through the comparative analysis. There are many known LCA software such as SimaPro, Tally, Umberto, BEES, Athena, Open LCA and others. For 
this study, SimaPro-Ecoinvent database and Tally-GaBi database are selected to evaluate their outcomes. From the existing literature, SimaPro is recognized as the premier research tool $[27,28]$. Tally was designed for professionals in the building sector and facilitates the alphanumeric and graphic data exchange from Revit, also the number one Building Information Modeler (BIM) platform. To the best of our knowledge, none of the previous studies compared the outcomes from SimaPro-Ecoinvent database and Tally-GaBi database

\subsection{Assumptions}

For this research, a series of assumptions have been adopted but are listed in the appropriate context within the article.

\subsection{Scope of Study}

\subsubsection{Case Study: Adohi Hall Mass Timber Building}

Adohi Hall is a 200,000- $\mathrm{ft}^{2}$ 708-bed complex and is the largest mass timber residential structure in the U.S. Adohi Hall is a multifunction building, with basement and ground floors consisting of back-of-house, business, storage, and small studios and assembly spaces. The upper levels contain primarily student residential units, with some business use and other support spaces. Adohi Hall has six wings and five floors. The structure of the building is predominantly CLT slabs supported by glulam columns and beams. The only exceptions are the basement and ground floor structure, which are built of concrete slabs and a combination of steel and concrete columns and beams. Approximately 1410 tonnes of CLT were used for roofs and interior floors (Source, Nabholz Construction Corp. \& MODUS Studio). Note that 1 tonne $=1000 \mathrm{~kg}$, and 1 U.S. ton $=0.907185$ tonne.

\subsubsection{System Boundaries}

The whole-building LCA standard EN 15978 [29] defines the stages of a building for LCA study. The system boundary of this specific study covers only module A4 in life-cycle stages, in definition from EN 15978. Figure 2 illustrates the building life cycle stages defined in the standard with module A4 highlighted.

\section{Building Life Cycle Information}
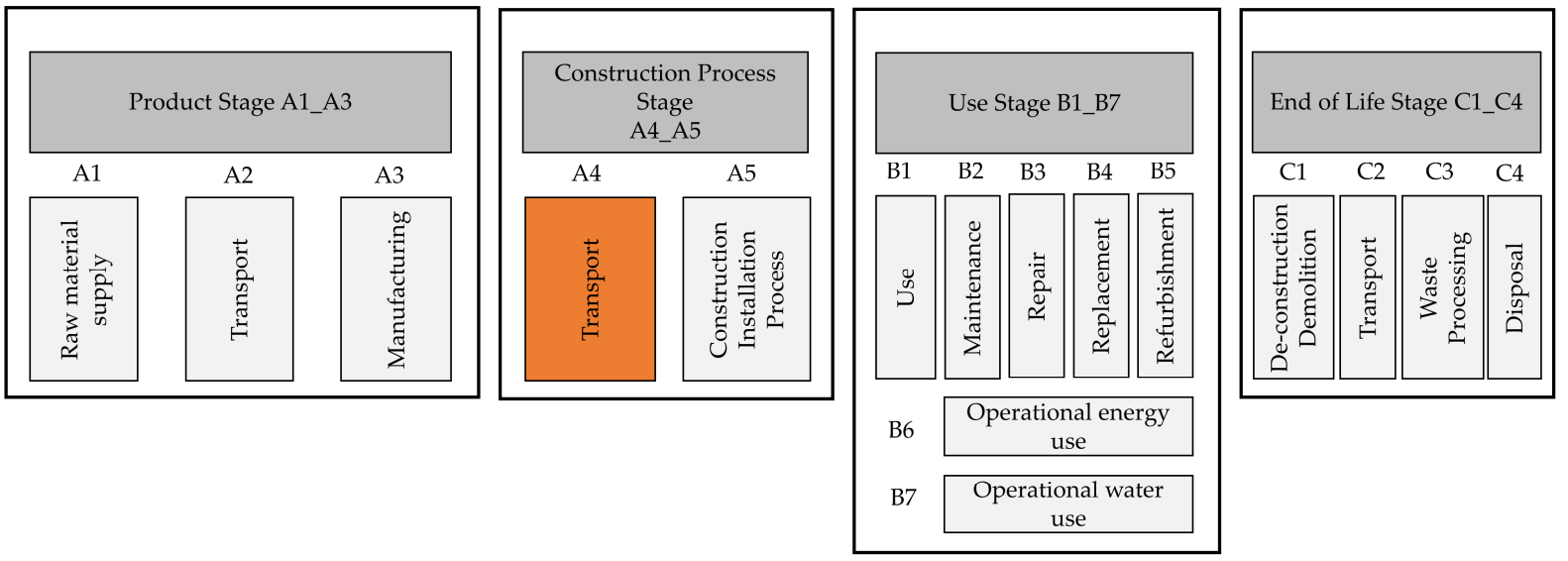

Figure 2. Building life cycle stages (Adapted from LCA standard EN 15978 [29]).

In this standard, module A4 covers the environmental impacts related to transportation aspects (transportation of materials and construction equipment to and from the building construction site). However, it should be mentioned this study covers transportation of materials but not equipment. Moreover, the study is limited to CLT utilized in the slabs for 
roofs and interior floors. Additional materials like screws, tapes, and similar objects, which are considered of less environmental influence, are therefore not considered here.

\subsection{LCA Tools and Database}

Recently, a big market opened for software to conduct LCA projects (e.g., SimaPro, One-click LCA, Umberto, Open LCA, Tally, etc.) [30]. Among them, SimaPro [31] is one of the leading tools in academia because it is equipped with the scientifically approved, world-wide-accepted databases and methods, and also a flexible user-defined modeling. Conversely, Tally is a tool specifically designed for conducting LCA projects in the building industry. Tally works as an extension on Revit, and it can easily take out the building material inventory data from the Revit 3D model and conduct a whole building LCA with its equipped life cycle inventory (LCI) and environmental product declaration (EPD) data. Tally is a good tool for architects to use at the early design phase for smart material choice, but it has less room and flexibility for LCA practitioners or scientific researchers to examine potential strategies to reduce impacts through LCA modeling. For these reasons, the authors decided to use SimaPro version 9.1.0.8 and Tally noncommercial version 2020.02.28.01 to conduct the LCA and compare the results.

SimaPro is equipped with libraries that include databases and worldwide methods to calculate predefined environmental impacts associated with materials and processes. Even though the U.S. Life Cycle Inventory (USLCI) database, a collection of LCI datasets based on U.S. context, is available, the Ecoinvent version 3.7.1 database [32], developed by the Swiss Centre for Life Cycle Inventories [33], is the one opted for in this study because the transportation involves both European and U.S contexts. While Ecoinvent was developed in Europe, the materials and processes in this database are representative of not only Europe but also a variety of geographical regions around the world. For example, some processes are modeled based on global activity (GLO). Using the suffix $\{G L O\}$ in Ecoinvent means an average of all production of a product in the world. In other words, the inventory is modeled for global activities. Suffix \{US\} means the inventory is modeled for the United States, and suffix $\{\mathrm{PER}\}$ means the inventory is modeled for Europe. There are many other geography suffixes in Ecoinvent database. Furthermore, suffix $\{$ RoW $\}$ is defined to be used for geographies that have no databases representing them in Ecoinvent. As such, suffix $\{R o W\}$ means the inventory is modeled for Rest-of-World [32].

On the other hand, Tally uses a custom designed LCA database. This tool automatically combines material attributes, assembly details, and architectural specifications in Revit model with associated environmental impact data. Tally is an LCA tool jointly developed between KT Innovations, Thinkstep and Autodesk. LCA modeling in Tally is run by combining Revit and an LCA tool called GaBi, version 8.5 [34].

\subsection{LCA Outcomes Determination}

There are many procedures for calculating the mid-point or end-point damage to human health, ecosystem quality, climate change, resource depletion, and other factors, and classifying the damage into different impact categories, such as GWP, Ozone depletion, or Smog. TRACI (Tool for Reduction and Assessment of Chemicals and Other Environmental Impacts) tool [35], the modeling engine, was selected for two reasons. TRACI is a procedure developed by EPA for North American impact assessments. The environmental impacts from Tally software are also based on TRACI 2.1. The same tool is selected in SimaPro LCA modeling for direct comparison of the results.

\section{Travel Pathways Definition and Data Input for Modeling}

\subsection{Transportation Origins and Pathways}

The transportation route of CLT from Austria to the construction site is inventoried based on the information provided by both Binderholz factory representative and Nabholz Construction contractor. The CLT was produced at the Binderholz factory in Graz-Styria, Austria, and transported by trucks from the plant to the Koper port in Slovenia, then 
shipped by containers to the Houston port in Texas, USA. The containers were unloaded from the ship and transported to the Houston railyard by truck to be moved by train to Dallas, Texas. In the last leg, they were dispatched by truck from the Dallas railyard to the construction site on the University of Arkansas campus, Fayetteville, Arkansas.

Figure 3 shows the various legs of transportation, and Table 1 presents the way CLT was transported in each leg and the associated distance.

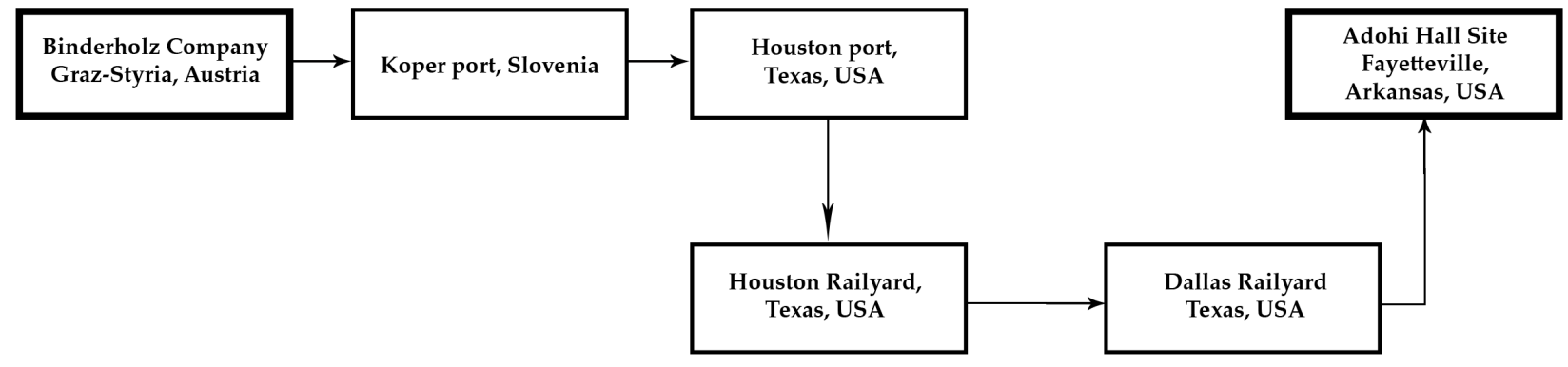

Figure 3. Transportation path of CLT panels from Graz-Styria, Austria to Fayetteville, AR, USA.

Table 1. Transportation from Graz-Styria, Austria to Site located at University of Arkansas campus, Fayetteville, AR, USA.

\begin{tabular}{cccc}
\hline From & To & Transport System & Distance \\
\hline Binderholz Company, & Koper port, Slovenia & Truck & $248 \mathrm{~km}$ \\
Graz-Styria, Austria & Houston port, TX & Ship & $13,690 \mathrm{~km}$ \\
Koper port, Slovenia & Houston Railyard, TX & Truck & $4.8 \mathrm{~km}$ \\
Houston port, TX & Dallas Railyard, TX & Train & $1375 \mathrm{~km}$ \\
Houston Railyard, TX, & Adohi Hall site, Fayetteville, AR & Truck & $534 \mathrm{~km}$ \\
Dallas Railyard, TX & Ad & &
\end{tabular}

Information collected from the building Revit model and Binderholz company's transactions indicate that the total CLT was transported in 92 containers. The contractor's representative indicated that 46 trucks were used for road transportation. An average of 40-min time is assumed to load or unload each truck prior to the CLT loading into the containers which on average take $20 \mathrm{~min}$ for loading or unloading.

\subsection{Data Input for LCA Modeling}

The accuracy of the collected data is vital to the proper modeling of the building in correctly determining the inherent GWP. In this case, most of the data are directly gathered. Detailed transportation information collected from the product manufacturer and building construction team is presented in Table 2.

Next the LCI datasets for these transportation paths were used as input into SimaPro and Tally. The Ecoinvent 3 database in SimaPro and GaBi 2018 database in Tally are used based on ISO 14040 and ISO 14044 environmental management standards. Tables 3 and 4 present the CLT transportation simulation in Tally and SimaPro, respectively.

According to the whole building LCA standard EN 15978 [29], Module A4 involves material and equipment transportation, which also includes the loading and unloading process. In Tally, only distances for each transportation category (water, rail, road) can be modeled with collected data, and the calculation is performed based on the default LCI datasets. No leverage option is provided to add more detail information or make modifications to the datasets (Table 3). SimaPro is a more flexible tool for modeling, compared to Tally. The modeler can select the most appropriate LCI datasets among all those provided by the software, consistent with specific details of the project. Among the available load factors, and considering the heavy nature of the loaded materials, a high load factor diesel operation machine with value boundaries $\geq 18.64 \mathrm{~kW}$ and $<74.57 \mathrm{~kW}$ power range is selected from the database for loading and unloading processes. For transportation 
by truck in Europe, the Europe-based data, with $\{P E R\}$ suffix, is used, but for transportation by rail in the United States, the U.S.-based data, with \{Us\} suffix, is employed. For those that have no U.S.-based inventory data modeled in the Ecoinvent, like transportation by truck and container ship, the database with $\{$ RoW $\}$ suffix data and $\{G L O\}$ suffix is applied.

Table 2. The inventory data of transportation of CLT panels from Graz-Styria in Austria to Fayetteville in AR, USA.

\begin{tabular}{|c|c|c|c|c|}
\hline & Activity & Scope of the Activity & Unit & Quantity \\
\hline 1 & Loading CLT packages to the trucks & Loading & Minute & 46 trucks $\times 40 \mathrm{~min}$ \\
\hline 2 & $\begin{array}{c}\text { Transportation from Binderholz company in } \\
\text { Graz-Styria to Koper port, Slovenia }\end{array}$ & Transport by truck & Tonne.km & 1410 tonnes $\times 248 \mathrm{~km}$ \\
\hline 3 & Loading CLT packages from trucks to the containers & Loading & Minute & 46 trucks $\times 40 \mathrm{~min}$ \\
\hline 4 & Loading containers to the ship & Loading & Minute & 92 containers $\times 20 \mathrm{~min}$ \\
\hline 5 & $\begin{array}{c}\text { Transport from Koper port in Slovenia to Houston } \\
\text { port in TX }\end{array}$ & Transport by ship & Tonne.km & 1410 tonnes $\times 13,690 \mathrm{~km}$ \\
\hline 6 & Unloading containers from ship to the trucks & Unloading & Minute & 92 containers $\times 20 \mathrm{~min}$ \\
\hline 7 & Transport from Houston port to Houston railyard & Transport by truck & Tonne.km & 1410 tonnes $\times 4.8 \mathrm{~km}$ \\
\hline 8 & Unloading containers from trucks to the train & Unloading & Minute & 92 containers $\times 20 \mathrm{~min}$ \\
\hline 9 & Transport from Houston railyard to Dallas railyard & Transport by train & Tonne.km & 1410 tonnes $\times 1375 \mathrm{~km}$ \\
\hline 10 & Unloading containers from train to the trucks & Unloading & Minute & 92 containers $\times 20 \mathrm{~min}$ \\
\hline 11 & Transport from Dallas railyard to the construction site & Transport by truck & Tonne.km & 1410 tonnes $\times 534 \mathrm{~km}$ \\
\hline 12 & Unloading containers at the construction site & Unloading & Minute & 92 containers $\times 20 \mathrm{~min}$ \\
\hline
\end{tabular}

Table 3. The LCIs chosen for CLT transportation from Tally/GaBi database.

\begin{tabular}{|c|c|}
\hline Activity & LCI Source \\
\hline $\begin{array}{l}\text { Transportation by } \\
\text { Container Ship }\end{array}$ & $\begin{array}{c}\text { GLO: Container ship, } 27,500 \mathrm{dwt}^{1} \text { payload capacity, ocean going ts }{ }^{2}(2017) \\
\text { US: Heavy fuel oil at refinery }\left(0.3 \mathrm{wt} . \% \mathrm{~S}^{3}\right) \text { ts }(2014)\end{array}$ \\
\hline Transportation by Rail & $\begin{array}{c}\text { GLO: Rail transport cargo- }- \text { Diesel, average train, gross tonne weight } 1000 \mathrm{t} / 726 \mathrm{t} \\
\text { payload capacity ts (2017) } \\
\text { US: Diesel mix at filling station ts (2014) }\end{array}$ \\
\hline Transportation by Truck & $\begin{array}{c}\text { US: Truck-Trailer, basic enclosed / 45,000 lbs payload- } 8 \mathrm{~b}^{4} \text { ts (2017) } \\
\text { US: Diesel mix at filling station ts (2014) }\end{array}$ \\
\hline
\end{tabular}

Table 4. The LCIs chosen for CLT transportation from SimaPro/Ecoinvent database.

\section{Activity}

Transport by Ship

Transport by Rail

Transport by Truck

Transport by Truck

Operation Machin, Loading \& unloading
LCI Source

Transport, freight, sea, container ship $\{\mathrm{GLO}\}^{1} \mid$ market for transport, freight, sea, container ship | Cut-off ${ }^{2}$

Transport, freight train $\{\text { US }\}^{3} \mid$ market for I Cut-off

Transport, freight, lorry $>32$ metric ton, euro5 $\{\text { PER }\}^{4}$ | market for transport, freight, lorry $>32$ metric ton, EURO5 | Cut-off

Transport, freight, lorry $>32$ metric ton, euro5 $\{\text { RoW }\}^{5} \mid$ market for transport, freight, lorry $>32$ metric ton, EURO5 ${ }^{6}$ | Cut-off

Machine operation, diesel, $\geq 18.64 \mathrm{~kW}$ and $<74.57 \mathrm{~kW}$, high load factor $\{\mathrm{GLO}\}$ । market for I Cut-off

\footnotetext{
${ }^{1}$ The global activity represents an average of all barley production in the world. In other word, the inventory is modelled for global. ${ }^{2}$ Cut-off system Model: A system model describes how activity datasets are linked to form product systems. This model allocates burdens at the point where a product is sold and applies a cut-off at the point the recyclable material leaves the product system. ${ }^{3}$ The inventory is modelled for the United States. ${ }^{4}$ The inventory is modelled for Europe. ${ }^{5}$ The inventory is modelled for Rest-of-World. Datasets with this geography contain data for the rest of the world datasets which are not represented in the Ecoinvent database. ${ }^{6}$ All acceptable limits for exhaust emissions of new vehicles are issued by the European Emission Standards. Furthermore, the emission standards can also be found in the EU directives. [37]
} 


\section{Overseas Transportation Results}

The GWP impacts obtained from the two tools are presented in Table 5. Regardless of the difference in results between the two, both show that transportation by water has the most GWP impact, $127.9 \mathrm{~kg} \mathrm{CO}$ eq (SimaPro-Ecoinvent database) and $328.66 \mathrm{~kg} \mathrm{CO}_{2}$ eq (Tally-GaBi database) per tonne of transported CLT. Land transportation by train is second, $77.27 \mathrm{~kg} \mathrm{CO}_{2}$ eq (SimaPro-Ecoinvent database) and $59.28 \mathrm{~kg} \mathrm{CO}_{2}$ eq (Tally-GaBi database) per tonne of transported CLT. Transportation by truck is third, with $75.50 \mathrm{~kg} \mathrm{CO}$ eq (SimaPro-Ecoinvent database) and $42.97 \mathrm{~kg} \mathrm{CO}_{2}$ eq (Tally-GaBi database) per tonne of transported CLT. Loading and unloading processes have negligible impact compared to other transportation processes. Impacts from loading and unloading equipment use are not accounted for by Tally and therefore cannot be compared, although too insignificant to affect the results, $4.67 \mathrm{~kg} \mathrm{CO}_{2}$ eq per tonne CLT (based upon SimaPro result). GWP contribution from each leg of transportation to the total impact are shown in Figure 4. Based on SimaPro results, $45 \%, 27 \%, 26 \%$, and $2 \%$ of the GWP impacts, respectively, are associated with water transportation, rail transportation, road transportation, and machine operations. Tally indicates $76 \%, 14 \%$, and $10 \%$ of the GWP impacts, respectively associated with water, rail and road transportation. No LCI dataset for equipment operation is provided in Tally, thus no loading/unloading impact could be estimated. The results from the two LCA tools show a $34 \%$ difference between them (Table 5 ).

Table 5. GWP impacts per tonne CLT transportation from Graz-Styria in Austria to Fayetteville, AR, USA, comparing SimaPro-Ecoinvent database and Tally-GaBi database.

\begin{tabular}{cccc}
\hline & \multicolumn{2}{c}{ GWP Impacts per Tonne CLT Transportation } \\
\hline Activity (Process) Category & SimaPro & Tally & Difference $\%$ \\
\hline Transport by Truck & $75.5 \mathrm{~kg} \mathrm{CO}_{2}$ eq & $42.97 \mathrm{~kg} \mathrm{CO}_{2}$ eq & $43 \%{ }^{1}$ \\
Transport by ship & $127.9 \mathrm{~kg} \mathrm{CO}_{2}$ eq & $328.66 \mathrm{~kg} \mathrm{CO}_{2}$ eq & $61 \%$ \\
Transport by Train & $77.27 \mathrm{~kg} \mathrm{CO}_{2}$ eq & $59.28 \mathrm{~kg} \mathrm{CO}_{2}$ eq & $23 \%$ \\
Loading/Unloading & $4.67 \mathrm{~kg} \mathrm{CO}_{2}$ eq & - & - \\
Total & $285.34 \mathrm{~kg} \mathrm{CO}_{2}$ eq & $430.91 \mathrm{~kg} \mathrm{CO}_{2}$ eq & $34 \%$ \\
\hline
\end{tabular}

${ }^{1}$ The difference above is determined as follows: (100\%-(smaller number/larger number)) per row. For example, the $\%$ difference between Tally and SimaPro for trucks is: $(100 \%-(42.97 / 75.5))=43 \%$.

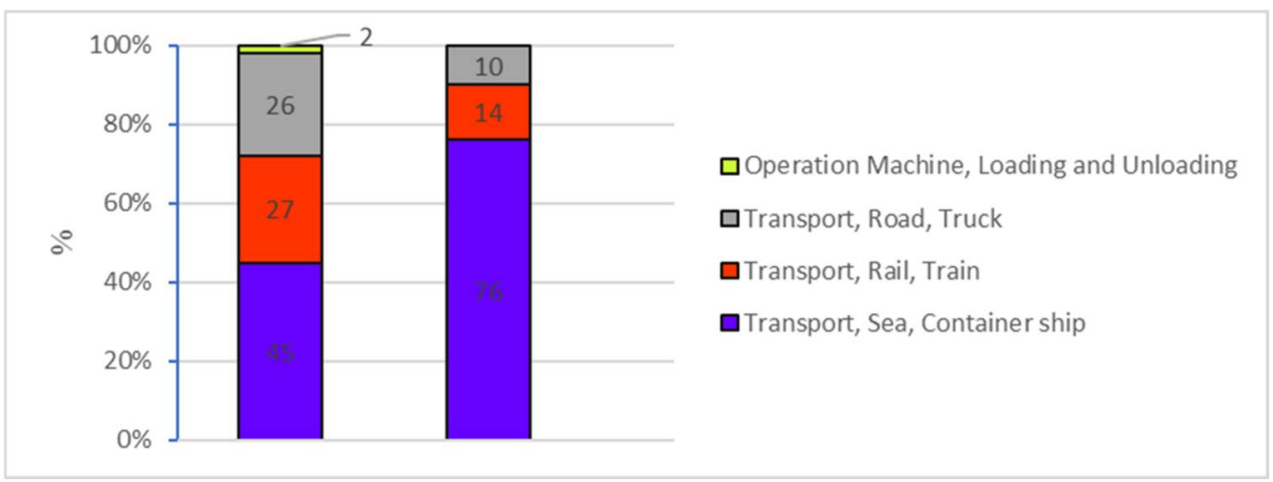

Figure 4. Contributions to the GWP per tonne of CLT transportation from Graz-Styria, Austria to Fayetteville, Arkansas, USA. (Left) SimaPro/Ecoinvent database, (right) Tally/GaBi database.

The GWP impact of each transportation per type obtained from the two tools is plotted in Figure 5 for comparison. Noticeable differences are observed in GWP impact per tonne transportation between Ecoinvent and GaBi databases. Figure 5 indicates emission quantities based on Ecoinvent and GaBi databases in terms of GWP impact of transportation by containership (water), train, and truck, respectively. 


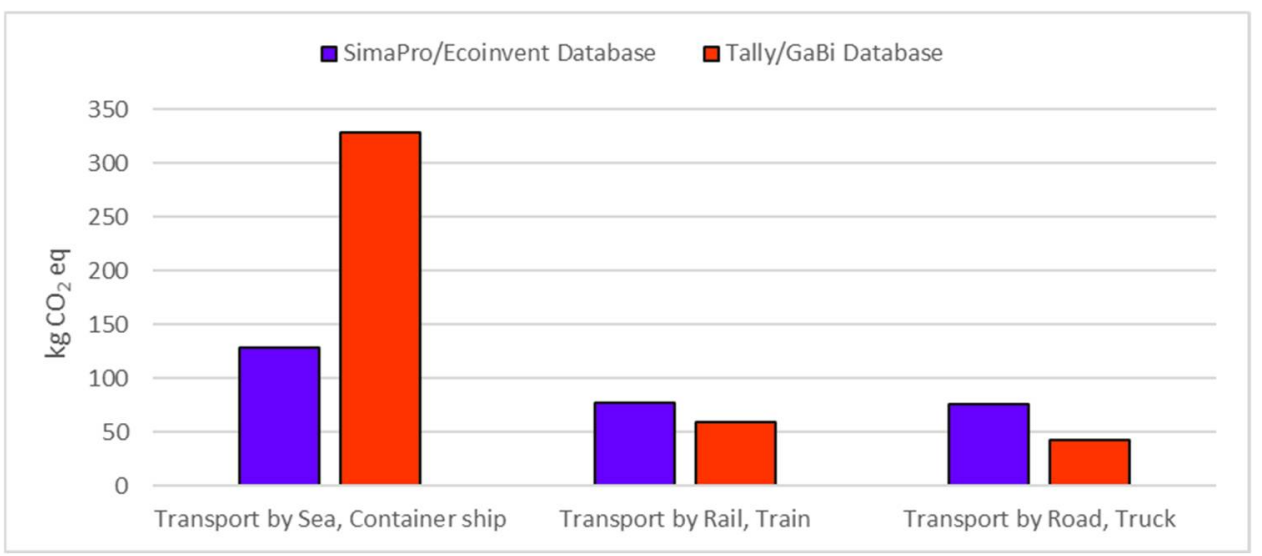

Figure 5. Comparing SimaPro/Ecoinvent \& Tally/GaBi database-in terms of GWP impact (per tonne CLT) of each transportation category used in this study.

\section{Comparison and Discussion}

\subsection{Comparatative Analysis and Discussion of Three CLT Transportation Scenarios}

Two other scenarios for domestic CLT product transportation are assumed and analyzed using the same model developed in SimaPro and Tally. At this point the comparison, therefore, involves three transportation scenarios. In scenario 1, CLT is transported from Graz-Styria, Austria to Fayetteville in Arkansas, USA (using imported CLT, real case). Scenario 2 assumes CLT being supplied from a factory in Seattle, Washington, DC, USA (using nationally produced CLT, assumed case). Scenario 3 assumes CLT being produced from a local plant, Structurlam mass timber manufacturer, in Conway, Arkansas, which is $255 \mathrm{~km}$ road distance (using locally produced CLT, assumed case). For scenario 2, a combination of transportation by truck and train is considered. With this hypothetical scenario, the CLT is dispatched by trucks from the plant to the railyard in Seattle, then transported by train to the railyard in Dallas, Texas, and then shipped by trucks from Dallas railyard to the construction site in Fayetteville, Arkansas. With scenario 3, the CLT panels are shipped from the plant to the construction site by truck because the railyard and trains in Conway are not equipped to transport the huge CLT panels. Currently, the most efficient way in terms of time and expense is transportation by truck (Structurlam company's representative at Conway, Arkansas). To the best of our knowledge, the adopted scenarios are the most realistic. The same types of trucks and trains are considered for road transportation as in scenario 1. Tables 6 and 7 show the LCIs used for the transport of CLT panels supplied from Seattle and Conway, respectively.

Table 6. LCIs of CLT panels from Seattle, WA, USA to Fayetteville, AR, USA.

\begin{tabular}{|c|c|c|c|c|}
\hline & Activity & Scope of the Activity & Unit & Quantity \\
\hline 1 & Loading CLT packages to the trucks & Loading & Minute & 46 trucks $\times 40 \mathrm{~min}$ \\
\hline 2 & $\begin{array}{l}\text { Transport from company in Seattle to } \\
\text { the railyard }\end{array}$ & Transport by truck & Tonne.km & 1410 tonnes $\times 9 \mathrm{~km}$ \\
\hline 3 & $\begin{array}{l}\text { Unloading CLT packages from trucks to } \\
\text { the train }\end{array}$ & Loading & Minute & 46 trucks $\times 40 \mathrm{~min}$ \\
\hline 4 & $\begin{array}{l}\text { Transport from railyard in Seattle the railyard } \\
\text { in Dallas }\end{array}$ & Transport by train & Tonne.km & 1410 tonnes $\times 2703 \mathrm{~km}$ \\
\hline 5 & $\begin{array}{l}\text { Unloading CLT packages from train to } \\
\text { the trucks }\end{array}$ & Loading & Minute & 46 trucks $\times 40 \mathrm{~min}$ \\
\hline 6 & $\begin{array}{l}\text { Transport from railyard in Dallas to the } \\
\text { construction site }\end{array}$ & Transport by truck & Tonne.km & 1410 tonnes $\times 534 \mathrm{~km}$ \\
\hline 7 & Unloading at the site & Unloading & Minute & 46 trucks $\times 40 \mathrm{~min}$ \\
\hline
\end{tabular}


Table 7. LCIs of CLT panels from Conway, AR, USA to Fayetteville, AR, USA.

\begin{tabular}{ccccc}
\hline & Activity & Scope of the Activity & Unit & Quantity \\
\hline 1 & Loading CLT packages to the trucks & Loading & Minute & 46 trucks $\times 40$ min \\
2 & Transport from company in Conway, AR to the site & Transport by truck & Tonne.km & 1410 tonnes $\times 255 \mathrm{~km}$ \\
3 & Unloading at the site & Unloading & Minute & 46 trucks $\times 40$ min \\
\hline
\end{tabular}

Based on these scenarios, GWP impact for module A4 of the life cycle of Adohi Hall is modeled using the same LCA tools mentioned above and according to the ISO standard. TRACI methodology is again used. In running the SimaPro model, the same databases are used for operation machines and transportation by truck and train. An average $40 \mathrm{~min}$ for loading or unloading each truck is assumed. Tables 8 and 9 illustrate the inventory data using Tally/GaBi database and SimaPro/Ecoinvent database, respectively.

Table 8. LCIs from Tally/GaBi database for two assumed Nationally and locally produced CLT transportation scenarios (scenarios 2 and 3).

\begin{tabular}{cc}
\hline Activity & LCI Resource \\
\hline Transport by Truck & US: Truck-Trailer, basic enclosed $/ 45,000$ lb payload-8b ts (2017) \\
& US: Diesel mix at filling station ts (2014) \\
\hline GLO: Rail transport cargo-Diesel, average train, gross tonne weight & $1000 \mathrm{t} / 726 \mathrm{t}$ \\
Transport by Train & payload capacity ts (2017) \\
& US: Diesel mix at filling station ts (2014) \\
\hline
\end{tabular}

Table 9. The LCIs chosen from SimaPro/Ecoinvent database for two assumed nationally and locally produced CLT transportation scenarios (scenarios 2 and 3).

\begin{tabular}{cc}
\hline Activity & LCI Resource \\
\hline Transport by Truck & $\begin{array}{c}\text { Transport, freight, lorry }>32 \text { metric ton, euro5 }\{\text { RoW }\} \mid \text { market transport, } \\
\text { freight, lorry }>32 \text { metric ton, EURO5 | Cut-off }\end{array}$ \\
\hline Transport by Rail & Transport, freight train $\{$ US $\} \mid$ market for $\mid$ Cut-off \\
\hline Loading \& unloading & $\begin{array}{c}\text { Machine operation, diesel, } \geq 18.64 \mathrm{~kW} \text { and }<74.57 \mathrm{~kW}, \text { high load factor } \\
\{\text { GLO }\} \mid \text { market for } \mid \text { Cut-off }\end{array}$ \\
\hline
\end{tabular}

Figure 6 shows an insignificant percentage of transportation GWP associated with loading and unloading processes in both scenarios. The main GWP load in scenario 2 is transportation by rail, 74.1\%, and in scenario 3 is transportation by truck, 95\%. Tables 10 and 11 show the results computed by both tools in detail. GWP impacts per tonne CLT transportation from Seattle and Conway to the site calculated by SimaPro are $204.92 \mathrm{~kg} \mathrm{CO}_{2} \mathrm{eq}$ and $24.95 \mathrm{~kg} \mathrm{CO}_{2} \mathrm{eq}$, respectively. The results by Tally represent much lower emissions than SimaPro. 


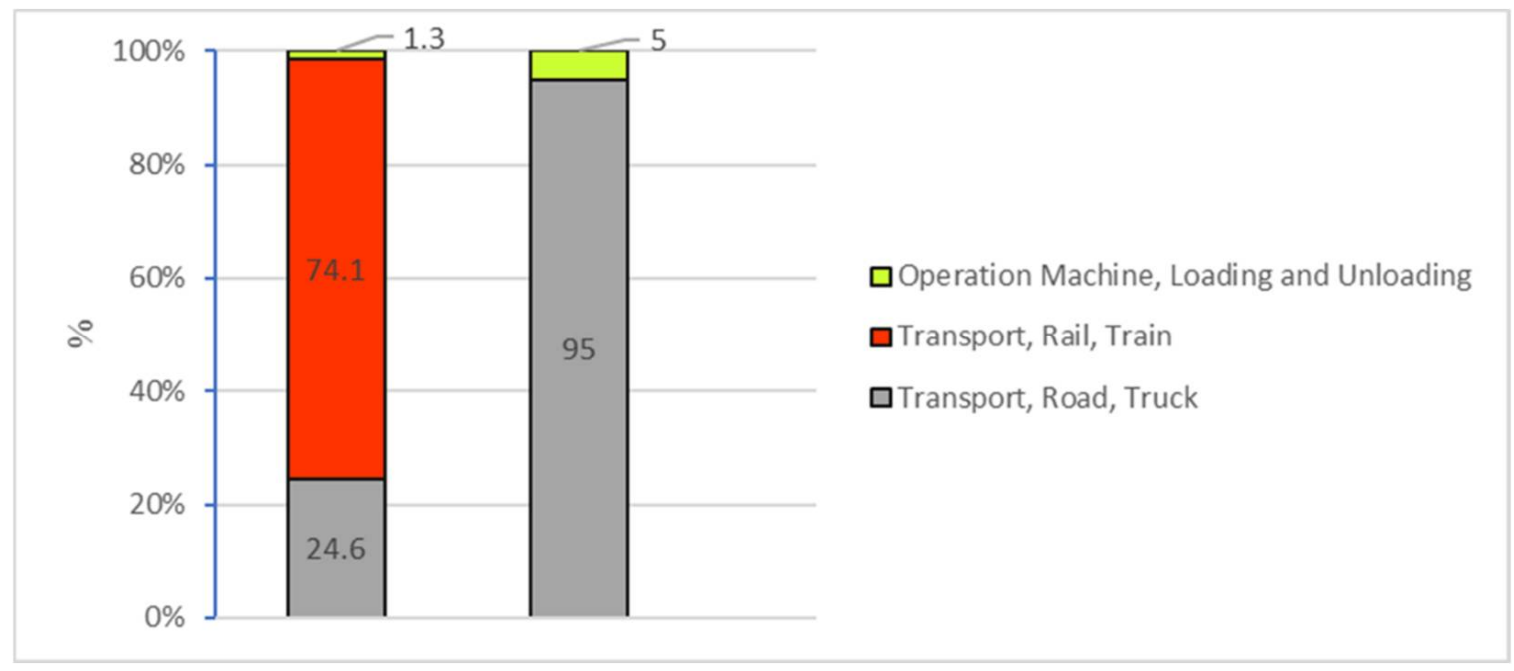

Figure 6. Analyzing GWP per tonne of CLT transportation, SimaPro-Ecoinvent database. (Left) Scenario2, (right) Scenario 3.

Table 10. GWP impacts per tonne CLT transportation for scenario 2, comparing SimaPro \& Tally.

\begin{tabular}{cccc}
\hline \multirow{2}{*}{ Activity (Process) Category } & \multicolumn{2}{c}{ GWP Impacts per Tonne CLT Transportation } \\
\cline { 2 - 4 } & SimaPro & Tally & Difference $\%$ \\
\hline Transport by Truck & $50.35 \mathrm{~kg} \mathrm{CO}_{2}$ eq & $29.66 \mathrm{~kg} \mathrm{CO}_{2}$ eq & $41 \%$ \\
Transport by Train & $151.9 \mathrm{~kg} \mathrm{CO}_{2}$ eq & $116.53 \mathrm{~kg} \mathrm{CO}_{2}$ eq & $23 \%$ \\
Loading and unloading & $2.67 \mathrm{~kg} \mathrm{CO}_{2}$ eq & - & - \\
Total & $204.92 \mathrm{~kg} \mathrm{CO}_{2}$ eq & $146.19 \mathrm{~kg} \mathrm{CO}_{2}$ eq & $29 \%$ \\
\hline
\end{tabular}

Refer to Table 4 for the calculation of the percentage difference.

Table 11. GWP impacts per tonne CLT transportation for scenario 3, comparing SimaPro \& Tally.

\begin{tabular}{cccc}
\hline \multirow{2}{*}{ Activity (Process) Category } & \multicolumn{2}{c}{ GWP Impacts per Tonne CLT Transportation } \\
\cline { 2 - 4 } & SimaPro & Tally & Difference $\%$ \\
\hline Transport by Road, Truck & $23.65 \mathrm{~kg} \mathrm{CO}_{2}$ eq & $13.93 \mathrm{~kg} \mathrm{CO}_{2}$ eq & $41 \%$ \\
Loading \& unloading & $1.33 \mathrm{~kg} \mathrm{CO}_{2}$ eq & - & - \\
Total & $24.95 \mathrm{~kg} \mathrm{CO}_{2}$ eq & $13.93 \mathrm{~kg} \mathrm{CO}_{2}$ eq & $44 \%$ \\
\hline
\end{tabular}

Refer to Table 4 for the calculation of the percentage difference.

Table 12 presents estimated GWP based on the developed model for each scenario, the comparison between these three scenarios using SimaPro and Tally, and the percentage difference between the tools. Regardless of the high level of differences, both tools illustrate that scenario 1 causes the most GWP impact, $285.34 \mathrm{~kg} \mathrm{CO} 2$ eq, and $430.91 \mathrm{~kg} \mathrm{CO}_{2}$ eq per tonne.km CLT transportation, respectively (SimaPro result is $34 \%$ less than the Tally result). Scenario 2, transporting CLT from Seattle to the site, has the second highest impact with $204.92 \mathrm{~kg} \mathrm{CO} 2$ eq and $146.19 \mathrm{~kg} \mathrm{CO}_{2}$ eq emission based on SimaPro and Tally, respectively (Tally result is $29 \%$ less than that of SimaPro). Scenario 3, transporting locally produced CLT from Conway (255 km from the construction site) has noticeably lower environmental impact than the two other scenarios, $24.95 \mathrm{~kg} \mathrm{CO}_{2}$ eq (SimaPro result) and $13.93 \mathrm{~kg} \mathrm{CO}_{2}$ eq (Tally result) emission per tonne of CLT transportation to the site. Likewise for this comparison, there is a $44 \%$ difference in outputs between the tools used for scenario 3 (Tally result lower than SimaPro). Comparative results in Figure 7 show the percentage difference between the two tools. 
Table 12. Comparing GWP impacts per tonne CLT transportation for each scenario.

\begin{tabular}{cccc}
\hline & \multicolumn{2}{c}{ GWP Impacts per Tonne CLT Transportation } \\
\cline { 2 - 4 } & SimaPro & Tally & Difference $\%$ \\
\hline Scenario 1 & $285.34 \mathrm{~kg} \mathrm{CO}_{2}$ eq & $430.91 \mathrm{~kg} \mathrm{CO}_{2}$ eq & $34 \%$ \\
Scenario 2 & $204.92 \mathrm{~kg} \mathrm{CO}_{2}$ eq & $146.19 \mathrm{~kg} \mathrm{CO}_{2}$ eq & $29 \%$ \\
Scenario 3 & $24.95 \mathrm{~kg} \mathrm{CO}_{2}$ eq & $13.93 \mathrm{~kg} \mathrm{CO}_{2}$ eq & $44 \%$ \\
\hline
\end{tabular}

Refer to Table 4 for the calculation of the percentage difference.

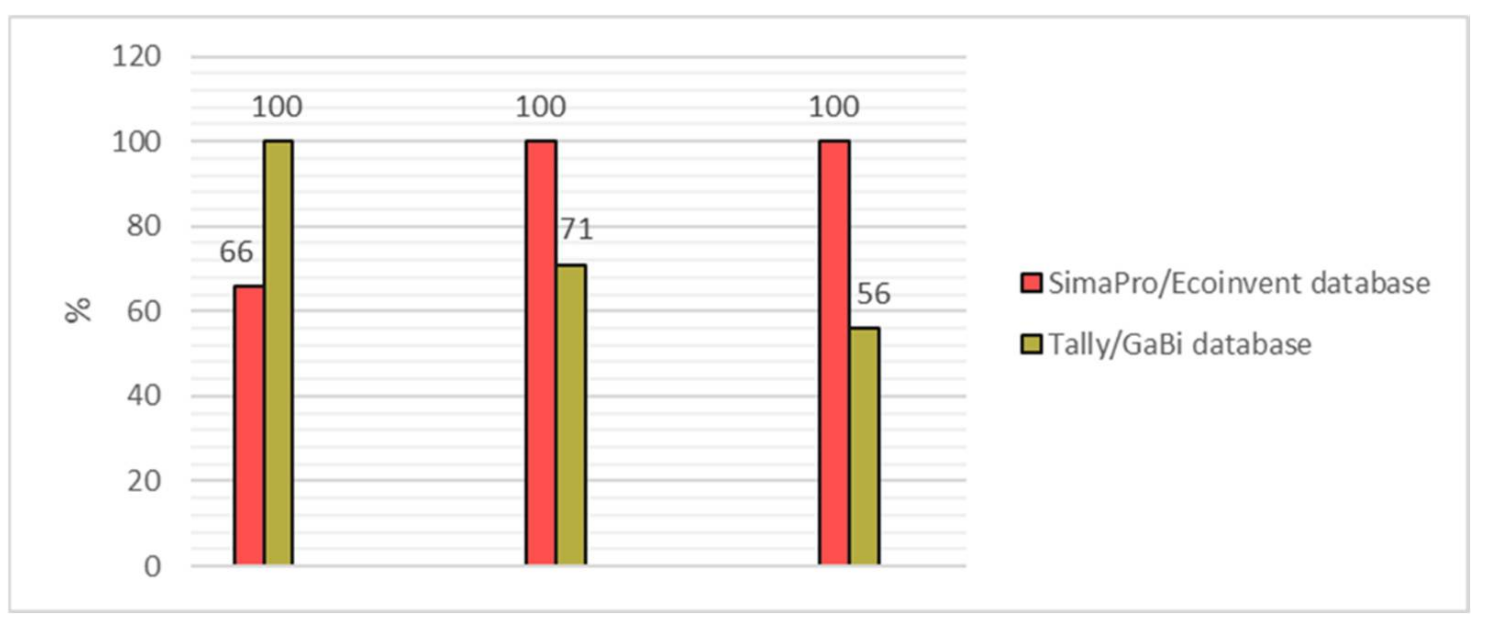

Figure 7. Comparing SimaPro-Ecoinvent and Tally-GaBi results for GWP potential of CLT transportation. (Left-right) Scenarios 1-3.

Among these three transportation scenarios, locally sourced CLT products (Conway, AR) result in the lower GWP impact and significantly lower than that the nationally (scenario 2) and internationally sourced (scenario 1) CLT transportation-see Figure 8.

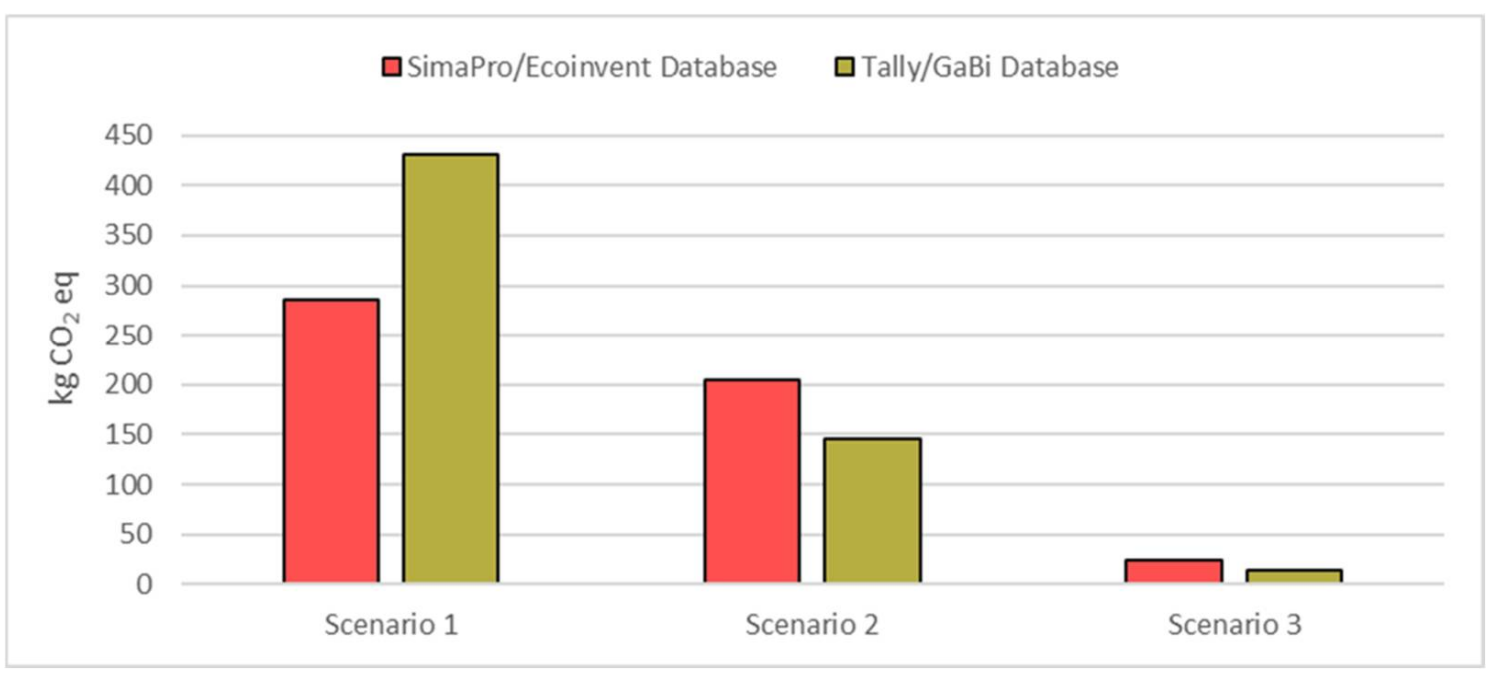

Figure 8. SimaPro \& Tally results for each scenario, GWP per tonne CLT transportation).

To shed more light on transportation efficiency, a fourth scenario was examined. The fourth scenario is comparable to scenario 2, sourcing CLT from Seattle, Washington, but transportation is assumed to be only by truck from Seattle to Fayetteville, Arkansas. The result shows $299.9 \mathrm{~kg} \mathrm{CO}_{2}$ eq emission, which is even about $5 \%$ higher than the scenario 1 of the international transportation impact (based on SimaPro results). This result shows that in addition to travel distance, the transportation system used is a significant factor and should be carefully considered in making decisions for moving materials. 


\subsection{Discussion of LCI for Transportation Mode}

Even though there is a remarkable difference between Tally and SimaPro results, both tools show that transportation by sea results in the most GHG emission among the three freight transportation paths in scenario 1 (Figure 5). This is mainly due to the long distance in sea transportation. LCIs of freight transportation by ship, train, and truck from the SimaPro and Tally were run for analysis using the TRACI method to obtain the GWP impacts. The used function unit is one tonne.km CLT transportation. Outputs from both tools, on the contrary, showed that transportation by ship has the least GWP characterization factor ("Characterization factors quantify the potential impacts that input and emissions have on specific impact categories in common equivalence units, such as GWP ( $\left.\mathrm{kg} \mathrm{CO}_{2} \mathrm{eq}\right)$ )" [6] (p. 5).) in comparison to that of train and truck, as shown in Figure 9.

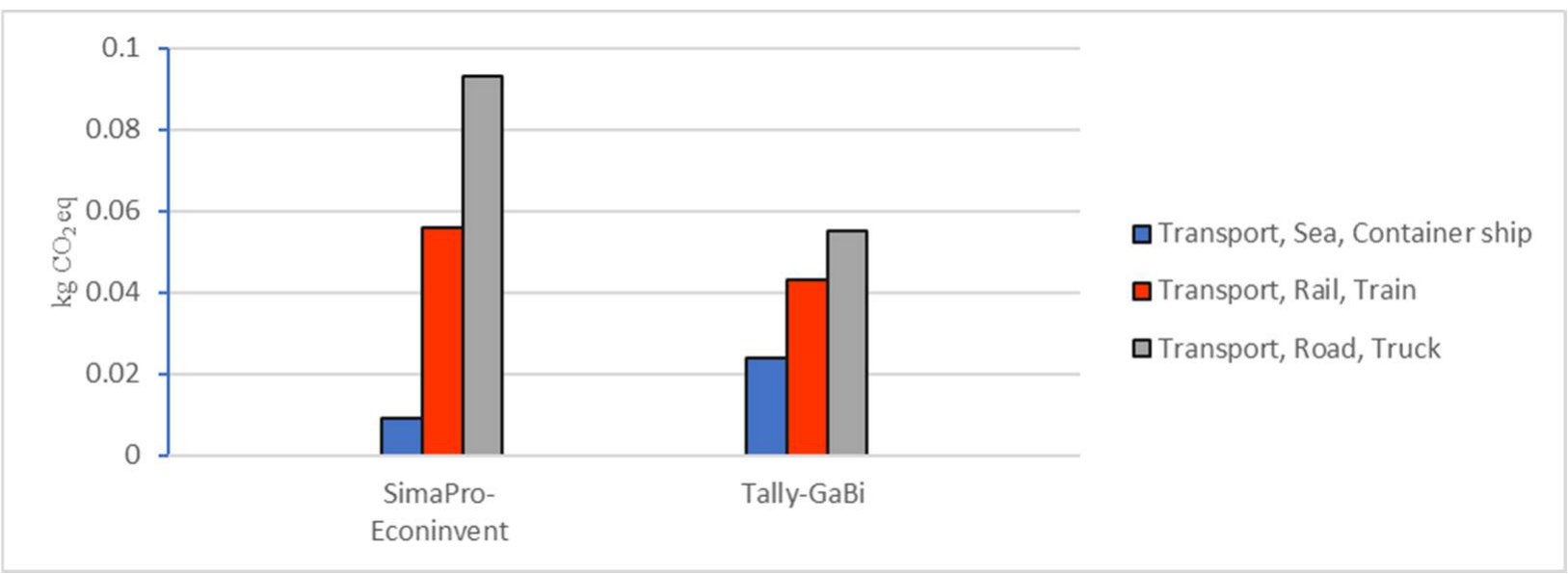

Figure 9. Comparing GWP characterization factor of one tonne.km transportation by container ship, train, and truck.

For every tonne.km transportation by container ship, train, and truck, GHG emissions are respectively estimated at $0.009,0.056$, and $0.093 \mathrm{~kg} \mathrm{CO}_{2}$ eq, based on Ecoinvent, and at $0.024,0.043$, and $0.055 \mathrm{~kg}$ of $\mathrm{CO}_{2}$ eq, based on the $\mathrm{GaBi}$ database. Comparing tools in Table 13 shows $62 \%, 23 \%$, and $41 \%$ difference between tools in terms of allocated characterization factor to transportation by water, rail, and road, respectively. The characterization factors are quite different between the two considered simulation tools. Further research is, therefore, needed to understand and explain the reasons for such differences, and to establish a calibrated procedure valid for both software tools and others. This effort is beyond the scope of this study.

Table 13. GWP characterization factors (for per tonne.km) in each transportation category, comparing of Ecoinvent and GaBi database.

\begin{tabular}{|c|c|c|c|c|}
\hline Transport Type & Tool/Data Source & $\begin{array}{l}\text { Emissions } \\
\text { (per tkm) }\end{array}$ & Unit & Difference \% \\
\hline Container ship & $\begin{array}{c}\text { SimaPro/Ecoinvent } 3 \\
\text { Tally/GaBi } 2018\end{array}$ & $\begin{array}{l}0.009 \\
0.024\end{array}$ & $\mathrm{~kg} \mathrm{CO}_{2} \mathrm{eq}$ & $62 \%$ \\
\hline Rail, Train & $\begin{array}{l}\text { SimaPro/Ecoinvent } 3 \\
\text { Tally/GaBi } 2018\end{array}$ & $\begin{array}{l}0.056 \\
0.043\end{array}$ & $\mathrm{~kg} \mathrm{CO}_{2} \mathrm{eq}$ & $23 \%$ \\
\hline Road, Truck & $\begin{array}{c}\text { SimaPro/Ecoinvent } 3 \\
\text { Tally/GaBi } 2018\end{array}$ & $\begin{array}{l}0.093 \\
0.055\end{array}$ & $\mathrm{~kg} \mathrm{CO}_{2}$ eq & $41 \%$ \\
\hline
\end{tabular}

Transporting by ship accounts for the highest contribution of GWP for scenario 1, while Figure 10 shows it has the least GWP characterization factors (per tonne.km) among all other transportation modes. Likewise, the characterization factors of the two transportation 
modes are much higher than ship transportation. The figure illustrates that ship transportation is the most environmentally efficient transportation system. Table 14 reveals that the GWP impact from the travel-by-water portion has the most contribution in the (A4) LCA results because of the longest travelled distance, $86 \%$ of the total transportation distance in scenario 1 . Only $9 \%$ and $5 \%$ of the total transportation is by rail and road, respectively.

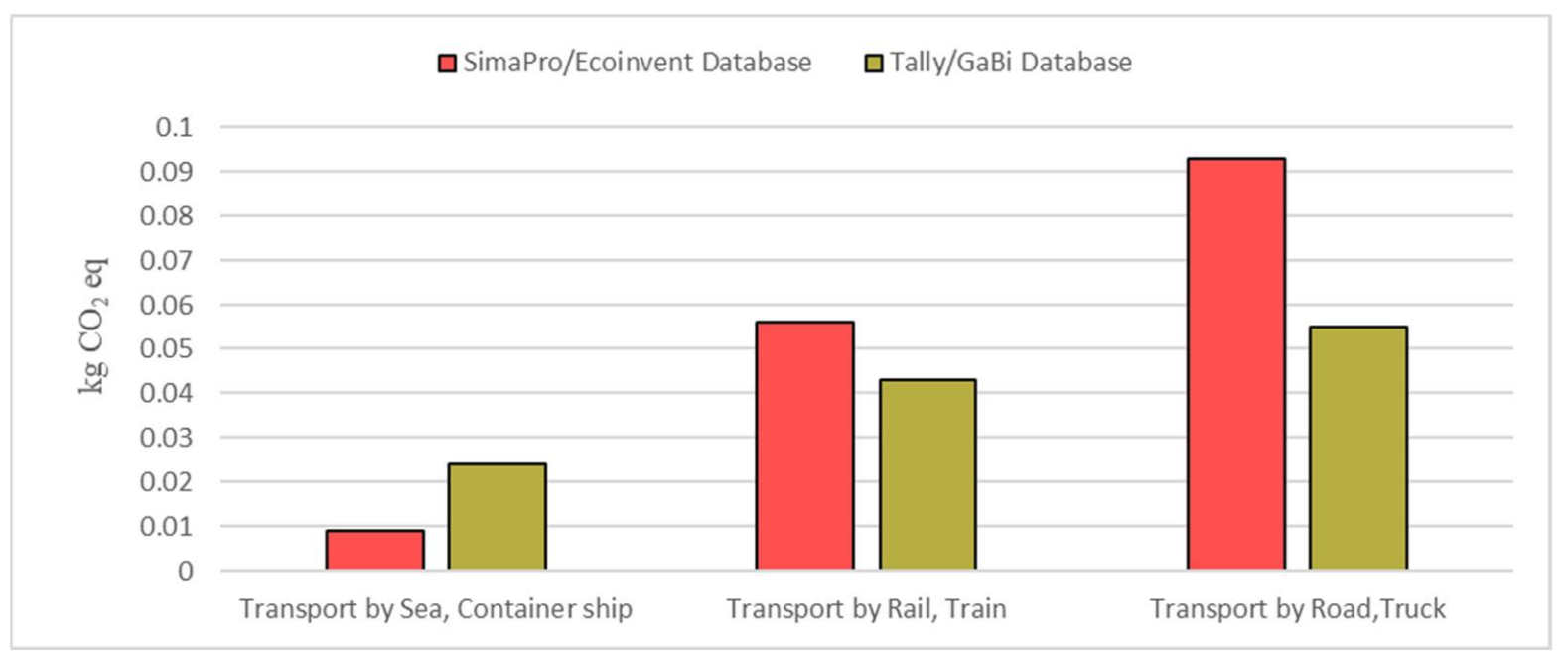

Figure 10. GWP characterization factors (per tonne.km) in each transportation category, comparing Ecoinvent and GaBi database.

Table 14. Contribution of each transportation type, ship, train, and truck travel in CLT transportation from Graz-Styria in Austria to Fayetteville, AR, USA.

\begin{tabular}{ccc}
\hline Transport Type & $\mathbf{k m}$ & Percentage \\
\hline Container ship & 13,960 & $86 \%$ \\
Train & 1375 & $9 \%$ \\
Truck & 787 & $5 \%$ \\
Total & 15,852 & $100 \%$ \\
\hline
\end{tabular}

Comparison of the two LCA tools reveals a substantial gap between their respective results. The main reason for such difference is the remarkable inconsistency between the defined GWP characterization factors for each transportation category in the databases. Figure 10 shows the GWP characterization factors (per tonne.km) in each transportation category for each tool. The highest inconsistency is observed in GWP characterization factors for water travel, 62\% difference between the Ecoinvent and GaBi databases (Table 13).

Another explanation is found in the custom designed LCA database of Tally. The modeler operates with fairly set database values once they enter the project location. One more problem with Tally is the absence of geographical databases suitable for international transportation to account for each leg of the route, with some of the processes completed in Europe, the United States, and in between. Tally's results are therefore not reliable enough for this specific case due to the limited functionality of the software. The limited regional selection aspects make this tool inappropriate, as more granularized databases are needed.

\subsection{Limitations of the Study}

For consistency of use, only the Ecoinvent database is applied in SimaPro, to the exclusion of all other data sources. While Ecoinvent contains worldwide datasets, it is not inclusive enough. For instance, U.S. databases are not included in Ecoinvent in some cases. In the SimaPro model, GWP impacts caused by some transportation legs, specifically those in the United States, are therefore calculated using datasets that are based on world averages. They are precise but not completely accurate relative to the U.S. 
context. Conversely, Tally limits the use of GaBi database to only one geographic location, the United States. This presented a challenge because the study requires both European and U.S.-based datasets. Moreover, the process-based inventory analysis technique is used in this LCA research. This technique is used to model the project from bottom to top. All involved materials and processes, which can be taken either as inputs or as resulting outputs, are considered in completing the information about a given product, in this case Adohi Hall $[38,39]$. It is important to note that process-based databases are not 100 percent accurate, and substantive errors are reported [40,41]. Thus, the use of such absolute values in this methodology should account for this deficiency. When only comparisons of various scenarios are sought using the same methodology, they provide, in relative terms, a magnitude of the environmental impacts [42].

Due to limited information about time spent in loading and unloading operations, assumptions were made about loading and unloading in each haul process. Even though these assumptions are based on estimations, the resulting impacts of loading and unloading are insignificant compared to the overall effects of transportation.

\section{Conclusions and Future Research}

In this study, the comparison of the two LCA simulation tools revealed serious differences in outputs between them. While SimaPro is more versatile, supporting a wider range of processes and databases, Tally is custom designed to building industry users in the United States. Unfortunately, this LCA analysis involved an international component (Styria-Graz, Austria) which could not be processed in Tally with a higher granularity. From this study, key issues are raised about accomplishing consistency, uniformity, normalization, and calibration between various LCA software applications. Societies and organizations involved with the development and promotion of LCA need to come together to establish internationally accepted metrics, processes, and modeling.

Despite all identified challenges, this study revealed, in relative terms, that the means of transportation combined with the travel distance are key factors affecting the GWP. As such, both factors should be carefully considered in the decision-making process related to shipment of materials.

The findings also indicate that the highest environmental impact is not necessarily associated with imported materials, and local products are not always the most environmentally efficient choice. Despite the indicated limitations, this work provides valuable insights regarding the environmental impact of the transportation phase in building projects. Moreover, these results could provide guidelines for moving forward to more environmentally efficient transportation of any other material in the supply chain.

After this study of the GWP associated with CLT transportation, the next steps will address, first, the outcomes resulting from the comparison with steel transportation for conventional building structure materials that are locally produced. Second, the study boundary will be expanded to the construction stage (module A5) and operation stage (module B6-B7) of Adohi Hall, in compliance with Standard EN 15978. Finally, the manufacturing stage of materials will be investigated. The energy systems used for manufacturing are different between Europe and the United States, and as such, will be investigated to determine the related quantities. The efficiency evaluation of the building GWP through the whole life cycle will provide results that help stakeholders in the building industry make the most environmentally appropriate decisions.

Author Contributions: Conceptualization, M.H. \& T.M.; methodology, M.H., T.M. \& H.G.; software, M.H.; validation, M.H., T.M. \& H.G.; formal analysis, M.H.; investigation, M.H.; resources, M.H.; data curation, M.H.; writing original draft preparation, M.H.; writing, review and editing, M.H., T.M. \& H.G.; visualization, M.H.; supervision, T.M. \& H.G.; project administration, T.M.; funding acquisition, T.M. All authors have read and agreed to the published version of the manuscript.

Funding: This project was financially supported by the United States Department of Agriculture [003691-00001] Forest Service, Forest Products Laboratory. The grant title is Life-cycle assessment and 
life-cycle cost analysis on Adohi Hall mass timber building, Fayetteville, AR 72701 USA, under Grant No. 20-JV-11111137-046.

Institutional Review Board Statement: Not applicable.

Informed Consent Statement: Not applicable.

Acknowledgments: The authors acknowledge Chris Baribeau, AIA, Principal and co-founder, Modus Studio, Leanne Baribeau, AIA, Architect, Modus Studio, Frank M. Allison, PE, President, Engineering Consultants Inc., Alex Font, PE, Senior Project Engineer at Engineering Consultants Inc., and Tyler Meenen, Assistant Project Manager at Nabholz Construction, for their help and support in providing the Revit model, the structures drawings, and related building materials information. Tom S. Chung, FAIA, Principal, Leers Weinzapfel Associates, graciously accepted to explain the process involved with the design of Adohi Hall and to share the related drawings. Antonio Guariento, President of New York-based Holzpak LLC, provided vital information related to the complex transportation journey of CLT from Austria to the site in Fayetteville, AR. The authors also acknowledge Greg Thoma of the University of Arkansas for providing access to SimaPro.

Conflicts of Interest: The authors declare no conflict of interest.

\section{References}

1. Bayer, C.; Gamble, M.; Gentry, R.; Joshi, S. AIA Guide to Building Life Cycle Assessment in Practice; The American Institute of Architects: Washington, DC, USA, 2010.

2. International Energy Agency. Directorate of Sustainable Energy Policy. In Transition to Sustainable Buildings: Strategies and Opportunities to 2050; Organization for Economic: Paris, France, 2013.

3. Rode, P.; Burdett, R.; Soares Gonçalves, J.C. Buildings: Investing in energy and resource efficiency Book section. In Towards a Green Economy: Pathways to Sustainable Development and Poverty Eradication; United Nations Environment Programme: Washington, DC, USA, 2011; pp. 331-373.

4. Dolezal, F.; Dornigg, I.; Wurm, M.; Figl, H. Overview and Main Findings for the Austrian Case Study. Sustainability 2021, 13, 7584. [CrossRef]

5. $\quad$ Liang, S.; Gu, H.; Bergman, R.; Kelley, S.S. Comparative life-cycle assessment of a mass timber building and concrete alternative. Wood Fiber Sci. 2020, 52, 217-229. [CrossRef]

6. Chen, Z.; Gu, H.; Bergman, R.D.; Liang, S. Comparative life-cycle assessment of a high-rise mass timber building with an equivalent reinforced concrete alternative using the Athena impact estimator for buildings. Sustainability 2020, 12, 4708. [CrossRef]

7. Eliassen, A.R.; Faanes, S.; Bohne, R.A. Comparative LCA of a concrete and steel apartment building and a cross laminated timber apartment building. IOP Conf. Ser. Earth Environ. Sci. 2019, 323, 012017. [CrossRef]

8. Pierobon, F.; Huang, M.; Simonen, K.; Ganguly, I. Environmental benefits of using hybrid CLT structure in midrise non-residential construction: An LCA based comparative case study in the US Pacific Northwest. J. Build. Eng. 2019, 26, 100862. [CrossRef]

9. Durlinger, B.; Crossin, E.; Wong, J.P.C. Life Cycle Assessment of a Cross Laminated Timber Building; RMIT University: Melbourne, VIC, Australia, 2013.

10. Jayalath, A.; Navaratnam, S.; Ngo, T.; Mendis, P.; Hewson, N.; Aye, L. Life cycle performance of Cross Laminated Timber mid-rise residential buildings in Australia. Energy Build. 2020, 223, 110091. [CrossRef]

11. Liu, Y.; Guo, H.; Sun, C.; Chang, W.S. Assessing cross laminated timber (CLT) as an alternative material for mid-rise residential buildings in cold regions in China-A life-cycle assessment approach. Sustainability 2016, 8, 1047. [CrossRef]

12. $\mathrm{Gu}, \mathrm{H} . ;$ Bergman, R. Life Cycle Assessment and Environmental Building Declaration for the Design Building at the University of Massachusetts; Gen. Tech. Rep. FPL-GTR-255; US Department of Agriculture, Forest Service, Forest Products Laboratory: Madison, WI, USA, 2018; Volume 255, pp. 1-73.

13. Take Action to Reduce the Carbon Emission of Building Materials. Available online: https://carbonleadershipforum.org/thecarbon-challenge/ (accessed on 5 February 2021).

14. Chen, C.X.; Pierobon, F.; Ganguly, I. Life Cycle Assessment (LCA) of Cross-Laminated Timber (CLT) produced in Western Washington: The role of logistics and wood species mix. Sustainability 2019, 11, 1278. [CrossRef]

15. Bribián, I.Z.; Capilla, A.V.; Usón, A.A. Life cycle assessment of building materials: Comparative analysis of energy and environmental impacts and evaluation of the eco-efficiency improvement potential. Build. Environ. 2011, 46, 1133-1140. [CrossRef]

16. Passarelli, R.N.; Koshihara, M. CLT panels in Japan from cradle to construction site gate: Global warming potential and freight costs impact of three supply options. Int. Wood Prod. J. 2017, 8, 127-136. [CrossRef]

17. Liang, S.; Gu, H.; Bergman, R. Environmental Life-Cycle Assessment and Life-Cycle Cost Analysis of a High-Rise Mass Timber Building: A Case Study in Pacific Northwestern United States. Sustainability 2021, 13, 7831. [CrossRef]

18. Emami, N.; Marteinsson, B.; Heinonen, J. Environmental impact assessment of a School building in Iceland using LCA-including the effect of long distance transport of materials. Buildings 2016, 6, 46. [CrossRef] 
19. Farkavcova, V.G.; Rieckhof, R.; Guenther, E. Expanding knowledge on environmental impacts of transport processes for more sustainable supply chain decisions: A case study using life cycle assessment. Transp. Res. Part D Transp. Environ. 2018, 61, 68-83. [CrossRef]

20. Thoma, G.; Popp, J.; Nutter, D.; Ulrich, R.; Matlock, M.; Kim, D.; Adom, F. Global warming potential of fluid milk consumed in the US: A life cycle assessment. In Proceedings of the LCAFood 2010, VII International Conference on Life Cycle Assessment in the Agri-Food Sector, Bari, Italy, 22-24 September 2010.

21. ISO 14040; Environmental Management: Life Cycle Assessment; Principles and Framework. International Organization for Standardization: London, UK, 2006.

22. ISO 14044; Environmental Management: Life Cycle Assessment; Requirements and Guidelines. International Organization for Standardization: London, UK, 2006.

23. Browne, M.; Rizet, C.; Anderson, S.; Allen, J.; Keïta, B. Life cycle assessment in the supply chain: A review and case study. Transp. Rev. 2005, 25, 761-782. [CrossRef]

24. Fries, N. Hellweg SLCA of land-based freight transportation: Facilitating practical application including accidents in, LCIA. Int. J. Life Cycle Assess. 2014, 19, 546-557. [CrossRef]

25. Meisterling, K.; Samaras, C.; Schweizer, V. Decisions to reduce greenhouse gases from agriculture and product transport: LCA case study of organic and conventional wheat. J. Clean. Prod. 2009, 17, 222-230. [CrossRef]

26. Peereboom, E.C.; Kleijn, R.; Lemkowitz, S.; Lundie, S. Influence of inventory data sets on life-cycle assessment results: A case study on PVC. J. Ind. Ecol. 1998, 2, 109-130. [CrossRef]

27. Säynäjoki, A.; Heinonen, J.; Junnila, S.; Horvath, A. Can life-cycle assessment produce reliable policy guidelines in the building sector? Environ. Res. Lett. 2017, 12, 013001. [CrossRef]

28. Emami, N.; Heinonen, J.; Marteinsson, B.; Säynäjoki, A.; Junnonen, J.M.; Laine, J.; Junnila, S. A life cycle assessment of two residential buildings using two different LCA database-software combinations: Recognizing uniformities and inconsistencies. Buildings 2019, 9, 20. [CrossRef]

29. EN 15978. 2011 Sustainability of construction works-Assessment of environmental performance of buildings-Calculation method. In European Committee for Standardization; CEN European Committee for Standardization, Management Centre: Brussels, Belgium, 2011; pp. 1-60.

30. Ciroth, A. Software for life cycle assessment. In Life Cycle Assessment Handbook; John Wiley \& Sons, Inc.: Hoboken, NJ, USA, 2012; pp. 143-157.

31. PRé Consultants, SimaPro. Available online: https:/ / www.pre-sustainability.com/ (accessed on 5 February 2021).

32. Wernet, G.; Bauer, C.; Steubing, B.; Reinhard, J.; Moreno-Ruiz, E.; Weidema, B. The Ecoinvent database version 3 (part I): Overview and methodology. Int. J. Life Cycle Assess. 2016, 21, 1218-1230. Available online: http:/ /link.springer.com/10.1007/s11367-016-1 087-8 (accessed on 5 February 2021). [CrossRef]

33. da Silva, V.P.; van der Werf, H.M.; Spies, A.; Soares, S.R. Variability in environmental impacts of Brazilian soybean according to crop production and transport scenarios. J. Environ. Manag. 2010, 91, 1831-1839. [CrossRef]

34. PEinternational, GaBi. Available online: http://www.gabi-software.com/ (accessed on 5 February 2021).

35. Bare, J. TRACI 2.0: The tool for the reduction and assessment of chemical and other environmental impacts 2.0. Clean Technol. Environ. Policy 2011, 13, 687-696. [CrossRef]

36. Deadweight Tonnage. Available online: https://en.wikipedia.org/wiki/Deadweight_tonnage (accessed on 13 December 2021).

37. European Emission Standards. Available online: https://en.wikipedia.org/wiki/European_emission_standards (accessed on 17 December 2020).

38. Mastrucci, A.; Marvuglia, A.; Leopold, U.; Benetto, E. Life Cycle Assessment of building stocks from urban to transnational scales: A review. Renew. Sustain. Energy Rev. 2017, 74, 316-332. [CrossRef]

39. Majeau-Bettez, G.; Strømman, A.H.; Hertwich, E.G. Evaluation of process-and input-output-based life cycle inventory data with regard to truncation and aggregation issues. Environ. Sci. Technol. 2011, 45, 10170-10177. [CrossRef] [PubMed]

40. Anderson, J.E.; Wulfhorst, G.; Lang, W. Expanding the use of life-cycle assessment to capture induced impacts in the built environment. Build. Environ. 2015, 94, 403-416. [CrossRef]

41. Crawford, R.H.; Stephan, A.; Prideaux, F. Environmental Performance in Construction (EPiC) Database. 2019; 268p, ISBN 9780734054951. Available online: http://hdl.handle.net/2078/230034 (accessed on 24 December 2020).

42. de Oliveira Fernandes, M.A.; Keijzer, E.; van Leeuwen, S.; Kuindersma, P.; Melo, L.; Hinkema, M.; Gutierrez, K.G. Material-versus energy-related impacts: Analysing environmental trade-offs in building retrofit scenarios in the Netherlands. Energy Build. 2021, 231, 110650. [CrossRef] 